Gašparović, Blaženka; Plavšić, Marta; Bošković, Nikola; Ćosović, Božena; Reigstad, Marit. Organic matter characterization in Barents Sea and eastern Arctic Ocean during summer. Marine Chemistry. 105 (2007), 1-2; 151-165. DOI: 10.1016/j.marchem.2007.01.021 - Postprint Version

\title{
Organic matter characterization in Barents Sea and eastern Arctic
}

\section{Oceaduring summer}

\author{
Blaženka Gašparovića*, Marta Plavšića , Nikola Boškovića, Božena Ćosovića \\ Marit Reigstad ${ }^{\mathrm{b}}$ \\ ${ }^{a}$ Center for Marine and Environmental Research, Ruđer Bošković Institute, POB 180, HR-10002 \\ Zagreb, Croatia, ${ }^{b}$ Norwegian College of Fishery Science, University of Tromsø, N-9037 Tromsø,
}

Norway

*Corresponding author. Tel.: +38514561 148; fax: +38514680242.

E-mail address: gaspar@irb.hr (B. Gašparović)

\begin{abstract}
The characteristics and distribution of the organic matter (OM) pool were investigated in the northern Barents Sea shelf region and eastern Arctic Ocean in July 2004. The first results on the vertical and horizontal distributions of surface-active substances and folic acid are presented along with dissolved organic carbon (DOC) measurements and sulfur determination, and related to salinity, temperature, and chlorophyll $a(C h l a)$. Neutral and low acidity substances dominated the surface-active $\mathrm{OM}$ pool at all depths and stations investigated. Characterization of hydrophobic/hydrophilic properties of the OM revealed the dominance of more hydrophobic substances in the upper mixed layer and highly hydrophilic substances in deep waters. Electrochemically detectable organically bound sulfur was a minor component compared to the presence of inorganic forms of sulfur, $\mathrm{S}^{2-}, \mathrm{S}^{0}$, detected in concentrations up to $10 \mathrm{nmol}^{-1}$. DOC concentrations were more or less uniform in the entire
\end{abstract}


Gašparović, Blaženka; Plavšić, Marta; Bošković, Nikola; Ćosović, Božena; Reigstad, Marit. Organic matter characterization in Barents Sea and eastern Arctic Ocean during summer. Marine Chemistry. 105 (2007), 1-2; 151-165. DOI: 10.1016/j.marchem.2007.01.021 - Postprint Version

region, while SAS concentrations were elevated in the upper mixed layer. The OM pool was larger in the northern Barents Sea, east of Svalbard, than in the eastern Arctic Ocean station, north of Svalbard.

Keywords: organic matter; surface-active substances; folic acid; sulfur; Barents Sea; eastern Arctic

\section{Introduction}

The Barents Sea, a high latitude marine ecosystem, is one the most productive in the Arctic and supports one of the world's richest fisheries. Situated at the margins of the icecovered Arctic, the northern Barents Sea Shelf region is very sensitive to global climate change, influencing ice-cover, mixing processes and radiation. The northeastern part of the Barents Sea is seasonally ice covered. Primary production in the Barents Sea, such as in all high latitude ecosystems, is strongly controlled by physical forces. Different physical conditions such as ice cover, low pressure passage, water masses mixing depth, temperature of the Atlantic and the Arctic waters as well as the structure, position and dynamics of frontal systems and the marginal ice zone, make the Barents Sea a heterogeneous and dynamic system (Sakshaug, 2004; Wassmann et al., 2006). The importance of investigating OM in polar region is in understanding and predicting atmospheric carbon sequestration as well as its transformation to oceanic $\mathrm{OM}$ as the basis for net transport of carbon to the deep ocean. In order to understand and predict atmospheric-oceanic coupling and biogeochemical cycling in general it is most important to increase our knowledge of the composition of dissolved organic matter and its role in Polar Regions. The Arctic region is characterized by high 
Gašparović, Blaženka; Plavšić, Marta; Bošković, Nikola; Ćosović, Božena; Reigstad, Marit. Organic matter characterization in Barents Sea and eastern Arctic Ocean during summer. Marine Chemistry. 105 (2007), 1-2; 151-165. DOI: 10.1016/j.marchem.2007.01.021 - Postprint Version

phytoplankton assimilation of inorganic sulfate to dimethyl sulfide (DMS) (Matrai and Vernet, 1997). DMS is the major source of sulfur compounds emitted from the oceans to the atmosphere (Bates et al., 1992) and is undoubtedly important factor for global climate.

Although it is important to determine the concentration of DOC in seawater, it is essential that its chemical characteristics are better constrained if its role is to be understood. A major fraction of dissolved organic matter has escaped chemical characterization because of its dilute nature and troubles pre-concentrating it due to high salinity of marine samples. Surfaceactive substances (SAS) represent a large fraction of OM (Hunter and Liss, 1982) and are the main part of the OM being adsorbed at different phase boundaries. Hydrophobic organic substances, such as lipids, together with high molecular weight hydrophilic substances, such as polysaccharides and proteins, contribute to SAS pool in the seawater. Plankton derived OM is abundant in the higher molecular weight fractions (Amon and Meon, 2004), but also low molecular weight fraction could represent a significant proportion (amino acids, sugars, etc.) (Amon et al., 2001). Evaluation of the concentration and characteristics of the SAS present in marine samples can be achieved using electrochemical methods that allow direct measurements with no sample pretreatment (Ćosović and Vojvodić, 1982; Gašparović and Ćosović, 1994 and 1995). These methods provide the information about all coexisting adsorbable substances that are involved in the adsorption on the surfaces in a competitive manner (Ćosović, 1990). The studies on SAS in different seas have shown that increased surfactant activity in the upper layers is associated with autochthonous SAS production by the phytoplankton (Gašparović and Ćosović, 2001; Gašparović et al., 2005). In temperate waters SAS concentrations vary seasonally indicating transformation from biogenic SAS, found during phytoplankton productive period, to SAS of refractory character (Gašparović et al., 1998a, Gašparović and Ćosović, 2003). Extracellular secretion of surface-active organic matter during nutrient enriched phytoplankton culture growth has showed increased 
Gašparović, Blaženka; Plavšić, Marta; Bošković, Nikola; Ćosović, Božena; Reigstad, Marit. Organic matter characterization in Barents Sea and eastern Arctic Ocean during summer. Marine Chemistry. 105 (2007), 1-2; 151-165. DOI: 10.1016/j.marchem.2007.01.021 - Postprint Version

concentrations of both surface-active polysaccharides and proteins, in dissolved and particulate phases (Gašparović et al., 1998b).

Some well-defined organic molecules although present at very low concentrations, could play a significant role as indicators of the cycling of trace constituents and represent, as such, the markers of particular biogeochemical processes. Folic acid (FA) could be considered an indicator for some phytoplankton due to the significant correlation between biomarker pigments for cyanobacteria and green algae (zeaxanthine and chlorophyll $b$, respectively) and the concentration of FA (Plavšić et al., 2002). FA is widespread in marine waters and could play a role as a nutrient for some microorganisms and is released at the same time by other microorganisms (Le Gall and van den Berg, 1998; Plavšić et al., 1997). The spatial and seasonal distributions of FA depend on a sensitive balance between its production, consumption and UV-decomposition (Le Gall, van den Berg, 1998; Plavšić et al., 2002; Plavšić, 2004), indicating that FA should be regarded as a highly reactive compound in the sea.

Our investigation aimed to contribute to the characterization of the $\mathrm{OM}$ pool in the eastern Arctic region by coupling the DOC measurements with the determination of the spatial distribution of surface-active substances and folic acid. These substances are produced through phytoplankton activity, and could be indicators of OM-cycling processes, such as transformation and sinking. Electrochemically active sulfur species were also determined for the investigated area as they interact with the present $\mathrm{OM}$ and are part of the global sulfur cycling. 
Gašparović, Blaženka; Plavšić, Marta; Bošković, Nikola; Ćosović, Božena; Reigstad, Marit. Organic matter characterization in Barents Sea and eastern Arctic Ocean during summer. Marine Chemistry. 105 (2007), 1-2; 151-165. DOI: 10.1016/j.marchem.2007.01.021 - Postprint Version

\section{Materials and Methods}

\subsection{Study area}

Sampling was performed east of Svalbard in the northern Barents Sea (Stations IX-XI and XIII) and at one station off the shelf break north of Svalbard, eastern Arctic Ocean (Station VII) (Fig. 1, Table 1). Due to the long seasonal ice-cover and the presence of drift ice, measurements are sparse in this region. The investigated area was characterized by open-to closed drift ice. The stations were distributed from $82^{\circ} 24.9^{`}$ to $79^{\circ} 23.3^{`} \mathrm{~N}$ (Table 1).

\subsection{Sample collection, processing and analysis}

Seawater was sampled at five stations from July 23 to 31,2004 with the R/V "Jan Mayen". Five-liter Niskin bottles were used for seawater sampling. Water samples were obtained from fixed depths $(1,5,10,20,30,40,50,60,90,120,150,200,300,400$ and 500 $\mathrm{m})$, or from as deep as the station depth allowed (Table 1). Under-ice seawater was sampled by divers. Some electrochemical measurements were performed immediately after sampling in the ship laboratory while other samples were deep-frozen and analyzed subsequently on land. For the dissolved OM determination, seawater samples were filtered (- $50 \mathrm{kPa})$ using precombusted Whatman $\mathrm{GF} / \mathrm{F}$ glass fiber filters $(0.7 \mu \mathrm{m}$ pore size $)$ after $5 \mathrm{~h}$ of combustion at $450{ }^{\circ} \mathrm{C}$.

At each station, continuous vertical profiles of temperature and salinity were determined with standard Sea-Bird SBE 9 and SAIV SD 204 CTD profilers attached to the rosette (Sundfjord et al., submitted)

\subsection{Pigments determination}


Gašparović, Blaženka; Plavšić, Marta; Bošković, Nikola; Ćosović, Božena; Reigstad, Marit. Organic matter characterization in Barents Sea and eastern Arctic Ocean during summer. Marine Chemistry. 105 (2007), 1-2; 151-165. DOI: 10.1016/j.marchem.2007.01.021 - Postprint Version

Chlorophyll $a(\mathrm{Chl} a)$ and phaeopigments were measured with a Turner Designs AU-10 fluorometer, calibrated with pure Chl a (C 6144, Sigma Chemical Co). Parallel samples (3 x $100 \mathrm{ml}$ ) where filtered on Whatman GF/F filters, extracted with $5 \mathrm{ml}$ of $100 \%$ methanol at room temperature in the dark. The samples were then centrifuged and analyzed according to Holm-Hansen and Riemann (1978). The mean standard deviation for all pigments was 0.069 $\mu \mathrm{g} \mathrm{L} \mathrm{L}^{-1}(n=112)$

\subsection{DOC analysis}

The DOC concentrations were analyzed in duplicate using the sensitive high temperature catalytic oxidation (HTCO) technique. A Model TOC-5000 System (Shimadzu) with high sensitive Pt catalyst and non-dispersive infrared (NDIR) detector for $\mathrm{CO}_{2}$ measurements was used. The mean standard deviation was $2.46 \mu \mathrm{mol} \mathrm{l}^{-1}(n=140)$, corresponding to expanded uncertainty of measurements at $\mathrm{k}=2(95 \%$ confidence level) to $7 \%$.

\subsection{Folic acid determination}

Electrochemical measurements of folic acid and sulfur were performed with a $\mu$-Autolab (Electrochemical Instruments, Eco Chemie) connected to a 663 VA stand (Metrohm), with static mercury drop electrode as the working electrode. The reference electrode was an $\mathrm{Ag} / \mathrm{AgCl}(3 \mathrm{M} \mathrm{KCl})$ electrode connected to the solution via an electrolyte bridge, and a platinum electrode served as the auxiliary electrode.

Folic acid was determined by differential pulse cathodic stripping voltammetry (Le Gall and van den Berg, 1993). Fig. 2 shows examples of voltammograms obtained for Barents Sea station XI at $10 \mathrm{~m}$ depth showing folic acid peaks at potential of $\mathrm{E} \approx-0.9 \mathrm{~V}$. Standard deviation of $6 \%$ was estimated for $0.5 \mathrm{nmol}^{-1}$ of FA (using an adsorption time of $60 \mathrm{~s}$ ), from which the detection limit of $0.09 \mathrm{nmol}^{-1}$ is calculated from $3 \sigma$. Sensitivity is $0.8 \mathrm{nA}$ per 1 
Gašparović, Blaženka; Plavšić, Marta; Bošković, Nikola; Ćosović, Božena; Reigstad, Marit. Organic matter characterization in Barents Sea and eastern Arctic Ocean during summer. Marine Chemistry. 105 (2007), 1-2; 151-165. DOI: 10.1016/j.marchem.2007.01.021 - Postprint Version

nmol $1^{-1}$ FA. The CSV sensitivity was calibrated by standard FA additions to the sample, buffered at $\mathrm{pH} 8.3$ with borate buffer $\left(1 \mathrm{~mol} \mathrm{l}^{-1}\right.$ of boric acid, $0.4 \mathrm{~mol} \mathrm{l}^{-1}$ of $\left.\mathrm{NaOH}\right)$ to the final concentration of $0.01 \mathrm{~mol} \mathrm{l}^{-1}$ of borate. The concentration of FA was determined by standard addition method by the procedure described in Le Gall and van den Berg (1993). Stock FA solutions were diluted daily from $0.02 \mathrm{~mol} \mathrm{~L}^{-1}$ of stock solution, which was prepared weekly in $0.01 \mathrm{~mol} \mathrm{~L}^{-1}$ of $\mathrm{NaOH}$ and kept in the dark at $4{ }^{0} \mathrm{C}$.

\subsection{Sulfur determination}

Determination of reduced organic and inorganic sulfur in seawater samples was performed by applying linear sweep voltammetry (LSV) (Ciglenečki and Ćosović, 1997; Krznarić et al., 2001). In Fig. 2 is presented voltammogram obtained for Barents Sea station $\mathrm{XI}$ at $10 \mathrm{~m}$ depth showing sulfur peak at potential of $\mathrm{E} \approx-0.64 \mathrm{~V}$. LSV was run with a scan rate of $100 \mathrm{mV} \mathrm{s}^{-1}$. Electrochemical determination of sulfur species is based on the reaction between sulfur and the mercury electrode. After accumulation of sulfur species on the electrode surface at the deposition potential $\mathrm{E}=-0.20 \mathrm{~V}$, potential scans were run to the negative direction (up to $\mathrm{E}=-1.00 \mathrm{~V}$ ) and $\mathrm{HgS}$ reduction peaks, characteristic of many sulfur species, were recorded (Ciglenečki and Ćosović, 1996). After degassing the sample with $\mathrm{N}_{2}$ at $\mathrm{pH}=2.0$, and readjusting the $\mathrm{pH}$ again to $\mathrm{pH}=8.0$ the concentration of $\mathrm{S}^{0}$ can be determined by repeating the electrochemical procedure. The difference between those two measurements represents concentration of $\mathrm{S}^{2-}$. The same method, modified by changing the deposition potential from $\mathrm{E}=-0.20$ to $\mathrm{E}=-0.40 \mathrm{~V}$ was used for distinguishing inorganic from organic sulfur species, following the method of Krznarić et al. (2001). Deposition at a potential E =$0.40 \mathrm{~V}$ would mainly yield a reduction peak of inorganic sulfur species $\left(\mathrm{S}^{0}, \mathrm{~S}^{2-}, \mathrm{S}^{\mathrm{x} 2-}\right)$, while deposition at $\mathrm{E}=-0.20 \mathrm{~V}$ would result in the sum of both organic and inorganic sulfur species. The concentration of sulfur species was determined from the calibration for $\mathrm{S}^{2-}$. 


\subsection{Characterization of $S A S$}

Surface-active substances were determined by phase-sensitive alternating current voltammetry using out-of-phase mode (Ćosović and Vojvodić, 1982). This electrochemical method is simple, nondestructive and does not need any pretreatment before measurements. The principle of the method is that SAS, when adsorbed on the mercury electrode surface, decrease interface capacitance. The concentration of SAS in natural seawater sample is expressed as the equivalent concentration of the nonionic surfactant Triton-X-100 (T-X-100), which produces the same effect as natural organic substances in the sample. The lower detection limit, expressed as T-X-100 concentration, is $0.02 \mathrm{mg} \mathrm{l}^{-1}$. In Fig. 3 the capacity current-potential curves are presented for samples taken at station X (5 and $150 \mathrm{~m} \mathrm{depth})$, indicating the presence of different concentrations of SAS on the two depths as well as predominance of different SAS material as seen from the different shapes of the voltammetric curves 2 and 3. Different organic substances, polysaccharides, proteins, lipids and humic type substances that are contributing to SAS pool are distinguishable by different desorption potentials and peak shapes (Vojvodić et al., 1994). Desorption peaks for highly hydrophobic SAS such as lipids appear at potentials around $-1.2 \mathrm{~V}$, while macromolecular substances exhibit desorption peaks at more negative potentials, around $-1.7 \mathrm{~V}$.

Characterization of SAS using o-nitrophenol as an electrochemical probe is based on the fact that electrochemical characteristics of o-nitrophenol (peak potential, height and shape, as well as prepeak height) change in significantly different ways depending on the properties of the adsorbed organic substances (hydrophobicity, acidity) As a result it is possible to distinguish between major organic groups, polysaccharides, proteins, lipids and refractory 
Gašparović, Blaženka; Plavšić, Marta; Bošković, Nikola; Ćosović, Božena; Reigstad, Marit. Organic matter characterization in Barents Sea and eastern Arctic Ocean during summer. Marine Chemistry. 105 (2007), 1-2; 151-165. DOI: 10.1016/j.marchem.2007.01.021 - Postprint Version

humic type substances, can be achieved (Gašparović and Ćosović, 1994; 1995). The shift of peak potential is indicator of OM hydrophobicity while the increase in prepeak height is an indicator of increasing OM acidity (Gašparović and Ćosović 1995, Gašparović et al., 1998b). Relative acidity is obtained from the normalization of relative increase in prepeak height $\left(\left(\mathrm{I}_{\mathrm{a}} / \mathrm{I}_{\mathrm{a} 0}-1\right)\right.$ to the surfactant activity (expressed as equiv. concentration of $\left.\mathrm{T}-\mathrm{X}-100\right)$. Relative acidity is an arbitrary unit of acidity per surfactant activity $\left(1 \mathrm{mg}^{-1}\right)($ Gašparović and Ćosović, 2003). The results were elaborated for total SAS $\left(\mathrm{SAS}_{\mathrm{T}}\right)$, dissolved SAS $\left(\mathrm{SAS}_{\mathrm{diss}}\right)$ and the

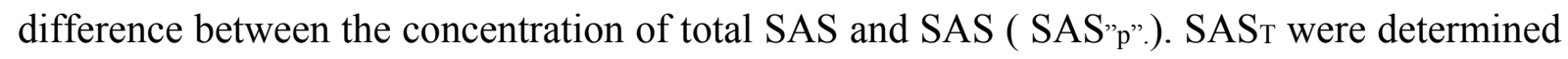
from the unfiltered sample, while $S A S_{\text {diss }}$ were determined from the filtered sample.

\section{Results}

\subsection{Hydrographic conditions and phytoplankton standing crop}

The investigated region is characterized by a heterogeneous mixture of waters, where the waters from the Atlantic are warmer and more saline than the Arctic waters, characterized by the sub zero temperatures and salinity below 34. Due to the extensive water mass transformation taking place in the Barents Sea, there is also evidence of water with intermediate characteristics resulting from cooling and freezing processes with brine formation and extensive mixing over shallow banks. The ice-cover was $30-80 \%$ at all stations, with the densest ice and the highest share of multiyear ice at Arctic Station VII. All stations showed a surface layer of depth $<10 \mathrm{~m}$, and a pycnocline (determined from the density) in the 20 - $40 \mathrm{~m}$ interval with reduced salinity above as a result of ice melting (Fig. 4) (Sundfjord et al., 2007). In the upper $50 \mathrm{~m}$ of Station VII in the Arctic Ocean Basin, water 
Gašparović, Blaženka; Plavšić, Marta; Bošković, Nikola; Ćosović, Božena; Reigstad, Marit. Organic matter characterization in Barents Sea and eastern Arctic Ocean during summer. Marine Chemistry. 105 (2007), 1-2; 151-165. DOI: 10.1016/j.marchem.2007.01.021 - Postprint Version

temperature was below $-1.7^{\circ} \mathrm{C}$, with salinity values $<34$ in the top $20 \mathrm{~m}$ depth. At Station XIII close to Kvitøya, high current speed was observed, and relatively homogeneous temperature and biomass distributions in the water column indicated strong vertical mixing. Further description of the hydrography is provided by Sundfjord et al. (2007).

The phytoplankton biomass, as reflected by the Chl $a$ distribution, is presented in Fig. 5 . The pigment distribution in late July and early August are indicative of a spring-summer situation (Reigstad et al., 2002), but influenced by variable ice conditions affecting the stage of the bloom. Chl a concentration was generally below $2 \mu \mathrm{g} \mathrm{1^{-1 }}$, indicating low algal biomass accumulation in the Barents Sea, and even lower algal biomass at the Arctic station. Significant subsurface maxima of 9.51 and $5.53 \mu \mathrm{g} \mathrm{1^{-1 }}$ were detected at Station XI at 30 and $40 \mathrm{~m}$ depths, respectively. The Chl a maxima were in general close to the pycnocline, restricted by nitrate availability (Sturluson et al., submitted). Only at Station VII nitrate was present throughout the water column. Based on the depth of the pycnocline (Sundfjord et al., 2007), the water mass in the study area was divided into two layers; the upper mixed layer (UML) and deep waters. The UML is defined as a layer where the mixing depth allowed phytoplankton cells to receive sufficient light to enhance their growth. The depth of the UML in the Arctic waters is usually determined by melt water and was found to be between 15 and $35 \mathrm{~m}$, while in the Atlantic waters it is thermally induced and closer to $50 \mathrm{~m}$ (Reigstad et al., 2002; Sakshaug, 2004). The Chl $a$ concentration in the UML was variable and showed the highest values at depths ranging from 10 to $40 \mathrm{~m}$, depending on the station. The deep waters contained very low $C h l a$ values with the average value of $0.33 \mu \mathrm{g} \mathrm{l}^{-1}$ for the measured samples. The lowest values were detected at Arctic Station VII, with the average value of 0.38 $\mu \mathrm{g} \mathrm{l^{-1 }}$ in the top $30 \mathrm{~m}$ and $0.07 \mu \mathrm{g} \mathrm{1^{-1 }}$ in the deep waters. 
Gašparović, Blaženka; Plavšić, Marta; Bošković, Nikola; Ćosović, Božena; Reigstad, Marit. Organic matter characterization in Barents Sea and eastern Arctic Ocean during summer. Marine Chemistry. 105 (2007), 1-2; 151-165. DOI: 10.1016/j.marchem.2007.01.021 - Postprint Version

Phaeopigment concentrations in the UML varied between $0.11-0.37 \mu \mathrm{g} \mathrm{1^{-1 }}$ (average 0.23 $\mu \mathrm{g}^{-1}$ ) for the Arctic station and between $0.29-3.24 \mu \mathrm{g}^{-1}$ (average $0.80 \mu \mathrm{g}^{-1}$ ) for the Barents Sea stations. In the deep waters phaeopigment concentrations varied between $0.01-$ $0.47 \mu \mathrm{g}^{-1}$ (average $0.20 \mu \mathrm{g} \mathrm{L}^{-1}$ ) for the Arctic station and between $0.06-0.85 \mu \mathrm{g} \mathrm{l}^{-1}$ (average $0.33 \mu \mathrm{g}^{-1}$ ) for the Barents Sea stations.

\subsection{Dissolved organic carbon}

DOC concentrations during this study ranged from 59.5 to $75.0 \mu \mathrm{mol} \mathrm{1^{-1 }}$ (Table 2), with an average value of $67.5 \mu \mathrm{mol} \mathrm{1^{-1 }}$. The Barents Sea stations exhibited higher DOC concentrations than those found at Arctic Ocean Station VII. The concentrations were relatively uniform with slightly higher DOC values found in the UML when compared to the values obtained in the deep waters. The difference was more pronounced at the Arctic station, where average DOC concentration was approximately $10 \%$ lower in the deep waters than in the UML. In the Barents Sea this difference was approximately $3 \%$.

\subsection{Folic acid}

Vertical distribution profiles of folic acid are shown in Fig. 6. The FA concentrations were mostly less than $1 \mathrm{nmol} \mathrm{l}^{-1}$, with the average concentration of all data $0.59 \mathrm{nmol} \mathrm{l}^{-1}$. Horizontal distribution of FA showed higher values in the Barents Sea $\left(0.76 \mathrm{nmol} \mathrm{l}^{-1}\right)$ in comparison to the Arctic station $\left(0.38 \mathrm{nmol} \mathrm{l}^{-1}\right)$. The highest value was found in the under-ice sample of Station XI ( $\left.3 \mathrm{nmol} \mathrm{l}^{-1}\right)$, and close to the bottom, at $120 \mathrm{~m}$ depth of Station XIII (2.3 nmol $1^{-1}$ ).

\subsection{Sulfur species}


Gašparović, Blaženka; Plavšić, Marta; Bošković, Nikola; Ćosović, Božena; Reigstad, Marit. Organic matter characterization in Barents Sea and eastern Arctic Ocean during summer. Marine Chemistry. 105 (2007), 1-2; 151-165. DOI: 10.1016/j.marchem.2007.01.021 - Postprint Version

In almost all samples from the Barents Sea including the Arctic station VII, the presence of sulfur species was determined (Table 5). The concentration of sulfur species was up to 10 $\mathrm{nM}$ (sample from station XI, $1 \mathrm{~m}$ depth). Sulfur was mainly present as inorganic species $\mathrm{S}^{2-}$ and $\mathrm{S}^{0}$. In some samples organic sulfur species were also observed (e.g. station $\mathrm{X}, 5$ and $20 \mathrm{~m}$; station VII, 1, 60 and 90 m; station XIII, 40 m).

\subsection{Surface-active organic substances}

The vertical distribution of total SAS in each of the investigated stations is shown in Fig. 7 (full lines). The Arctic station had lower SAS concentrations when compared to the Barents Sea stations, both in the surface and in deep waters. SAS concentrations were in the range between 0.022 and $0.056 \mathrm{mg} \mathrm{l}^{-1}$ equiv. to T-X-100 at Station VII. In the Arctic surface waters, the average value in the upper $30 \mathrm{~m}$ was $0.049 \mathrm{mg} \mathrm{l}^{-1}$ (including under-ice sample) whereas the value in the deep waters was $0.037 \mathrm{mg} \mathrm{l}^{-1}$. Stations IX - XIII in the Barents Sea showed SAS concentrations between 0.025 and $0.115 \mathrm{mg}^{-1}$ equiv. to $\mathrm{T}-\mathrm{X}-100$. Increased concentrations of SAS with substantial variations were detected in the UML. Below $50 \mathrm{~m}$ depth at the Barents Sea stations, the SAS average concentration was $0.045 \mathrm{mg} \mathrm{l}^{-1}$ equiv. to T$\mathrm{X}-100$.

The concentrations of the SAS"p" are presented in Fig. 7 (dotted lines). This fraction contributed to the SAST up to $47 \%$. There were no SAS"p" found in upper $30 \mathrm{~m}$ of the Arctic station while in the Barents Sea SAS"p" were present in the entire water column.

In Fig. 8 the relation between dissolved SAS and DOC concentration is given for the polar region investigated (the UML and the deep water samples are presented separately, open and full squares, respectively), for the subpolar region (north Norwegian fjords and shelf waters), for the depths down to $200 \mathrm{~m}$ (Gašparović et al., 2005) and for the moderate zone, the 
Gašparović, Blaženka; Plavšić, Marta; Bošković, Nikola; Ćosović, Božena; Reigstad, Marit. Organic matter characterization in Barents Sea and eastern Arctic Ocean during summer. Marine Chemistry. 105 (2007), 1-2; 151-165. DOI: 10.1016/j.marchem.2007.01.021 - Postprint Version

Adriatic Sea, 0 to $35 \mathrm{~m}$ depth (Gašparović, unpublished data). All samples were taken at the same time of year. The obtained values are also compared to the chosen model substances, representative for some of the major classes of organic compounds present in seawater: fulvic acid, proteins and polysaccharides (Fig. 8, curves 1, 2 and 3, respectively). The distinctive nature of the $\mathrm{OM}$ in the samples from the polar region in comparison to all other samples is obvious; in the Arctic and the Barents Sea samples the variations in SAS values are pronounced although the variations in DOC values were much less.

The concentration of SAS normalized to DOC (SAS/DOC) (Table 3) provides valuable information on the hydrophobic/hydrophilic characteristics of SAS mixture (Ćosović and Vojvodić, 2000; Gašparović et al., submitted). Higher SAS/DOC ratios indicate predominance of more hydrophobic SAS. As determined from the behavior of model substances, the highest SAS/DOC ratio have highly hydrophobic substances such as fatty acids (SA/DOC is 2.39 for model linoleic acid), for humic acids and proteins SAS/DOC values are 0.34 and 0.19 , while some polysaccharides like xanthan have a low SAS/DOC ratio (0.04) (Gašparović et al., submitted). The SAS/DOC values obtained for all samples were in the range between 0.029 and 0.127 . Higher values were observed for the surface waters, up to $30 \mathrm{~m}$ depth. SAS/DOC ratio is decreasing with depth, even for very hydrophilic substances, such as polysaccharides. Decreasing SAS hydrophobicity was observed towards higher latitude stations. This is also evident from the shapes of the voltammetric curves obtained for SAS in surface and deep waters as shown in Fig. 3. The voltammetric curve of the sample taken at $5 \mathrm{~m}$ depth exhibits a shape reflecting lipid-type substances, while the curve of the sample taken at $150 \mathrm{~m}$ depth exhibit shape of macromolecular substances.

The relative acidity of SAS is characteristic for different types of OM present in the marine environment. Model experiments, using the same experimental approach as here, showed that biogenic SAS such as polysaccharides, proteins and lipids, contribute less to the 
Gašparović, Blaženka; Plavšić, Marta; Bošković, Nikola; Ćosović, Božena; Reigstad, Marit. Organic matter characterization in Barents Sea and eastern Arctic Ocean during summer. Marine Chemistry. 105 (2007), 1-2; 151-165. DOI: 10.1016/j.marchem.2007.01.021 - Postprint Version

SAS relative acidity $\left(0\right.$ to $\left.\sim 151 \mathrm{mg}^{-1}\right)$ than the recalcitrant substances such as fulvic and humic acids $\left(\sim 20-251 \mathrm{mg}^{-1}\right)$ (Gašparović and Ćosović, 2003). Table 4 presents average values for the relative acidity of SAS present at the investigated stations. The evaluated mean relative acidities of SAS for the surface waters were $5.61 \mathrm{mg}^{-1}$ for the Arctic and $3.61 \mathrm{mg}^{-1}$ for the Barents Sea; for the deep waters relative acidities were 4.7 and $2.41 \mathrm{mg}^{-1}$, respectively. In Table 4 the determined relative acidity values are compared to those obtained for the northern sub-polar region, 8.2 - $26.31 \mathrm{mg}^{-1}$ (Gašparović et al., 2005) and for the temperate seawaters in the Mediterranean, $7.7-29.51 \mathrm{mg}^{-1}$ (Gašparović, unpublished data). Very low relative acidity values were detected at all investigated stations at all depths in the Arctic and the Barents Sea.

Concentrations of inorganic nutrients are repleted under the ice and the dissolution of ice leads to enhanced phytoplankton blooms (Hegseth, 1998). In Table 5 values of all measured and evaluated parameters for the under-ice samples from this distinctive area are collected. The data from under-ice samples showed no significant difference to those in adjacent seawater. In contrast, the under-ice sample of Station VII exhibited increased DOC and surfactant activity concentrations compared to the entire investigated water column of the same station.

\section{Discussion}

Organic matter in the northern polar region investigated can be considered to be of both autochthonous origin and advected by inflow waters and from melted ice drifted from the eastern shelves. Riverine OM should be insignificant since the region is not under the influence of the main Arctic rivers (Aagaard and Carmack, 1989; Andersson et al., 1994). OM 
Gašparović, Blaženka; Plavšić, Marta; Bošković, Nikola; Ćosović, Božena; Reigstad, Marit. Organic matter characterization in Barents Sea and eastern Arctic Ocean during summer. Marine Chemistry. 105 (2007), 1-2; 151-165. DOI: 10.1016/j.marchem.2007.01.021 - Postprint Version

is under the influence of various biogeochemical processes that lead to $\mathrm{OM}$ accumulation or losses. Phytoplankton biomass and composition in the region vary considerably and are dependent upon hydrological, chemical and biological factors, as well as upon the coverage and thickness of sea ice (Owrid et al., 2000; Andreassen et al., 1996; Falk-Petersen et al., 2000).

Moderate algal biomass (low Chl $a$ concentrations) was detected at most of the stations during this cruise. Open drift ice in the region in July is generally characterized by the depletion of nutrients in the surface waters when compared to winter and spring situation (Reigstad et al., 2002). No correlation was found between the $C h l a$ and salinity decrease, as an indicator of nutrient input from melt water. It was shown that both the new and regenerated productions occur in the investigated region in summer, however grazing by micro- and mesozooplankton exerts a major control (Owrid et al., 2000). Considerable vertical fluxes following the blooms also prevent long lasting biomass accumulations (Olli et al., 2002).

The increased contribution of phaeopigments in relation to Chl $a$ in the deep Arctic as compared to Barents Sea indicates enhanced degradation of phytoplankton derived material most likely a consequence of high grazing pressure.

The detected DOC concentrations (Table 2) agree well with the previous studies on the Arctic Eurasian basin (Amon and Benner, 2003; Amon, 2004; Fransson et al., 2001). Summer concentrations of DOC showed slightly higher values in the Barents Sea compared to the Arctic Ocean station. No significant difference was observed between the UML, the layer where phytoplankton grow, and the deep waters for the all stations. The cooling of the Atlantic water flowing north through the Barents Sea, along with the brine release during seaice formation (Midttun, 1989), increase the density of water, contributing to its penetration together with the OM to the intermediate and deep waters. DOM downwelling is suggested as a principal OM source to the deep waters of the Arctic Mediterranean Sea (Amon and Benner, 
Gašparović, Blaženka; Plavšić, Marta; Bošković, Nikola; Ćosović, Božena; Reigstad, Marit. Organic matter characterization in Barents Sea and eastern Arctic Ocean during summer. Marine Chemistry. 105 (2007), 1-2; 151-165. DOI: 10.1016/j.marchem.2007.01.021 - Postprint Version

2003). For our data set, the correlation of the DOC from surface waters and the salinity is statistically not significant. Therefore, the melted ice, as indicated by the decreased surface salinity, cannot be considered a significant source of OM in UML. Statistical analysis of the measured DOC and Chl a concentrations in the UML was performed to get the information on phytoplankton derived fresh OM; the obtained correlation coefficient, $R=0.33$ was statistically not significant. The four highest detected values of Chl $a$ did not reflect in any increase of the measured parameters concerning OM. It is suggested that during summer the DOC pool in the investigated region originated from multiple sources. Rapid turnover of labile DOC by bacteria, and grazing by zooplankton on the Chl a containing biomass, might also have weakened the correlation between DOC and Chl $a$ standing stock, although their production could have been correlated.

Folic acid is found in seawater and could be regarded as biomarker compound as it is a product of metabolism of some microorganisms (green algae and cyanobacteria) (Aaronson et al., 1977; Plavšić et al., 2002), while other microorganisms e.g. the diatom Phaeodactylum tricornutum (Plavšić et al., 1997) are FA consumers. However little is known on potential FA producers and consumers in the Arctic. FA concentrations were found in concentration range of 0.1 - $31 \mathrm{nM}$ for the coastal waters (Gašparović et al., 2005; Plavšić, 2004), while in North East Atlantic the FA concentrations were in the range 0.1 - $4 \mathrm{nM}$ (Le Gall and van den Berg, 1998). They found FA maximum in the euphotic zone $(30-100 \mathrm{~m})$ and a secondary maximum at about $500 \mathrm{~m}$. The deep water maximum was speculatively ascribed to the bacterial activity but this was not proved.

The detected low FA values in the UML of the Arctic Ocean and the Barents Sea in July 2004 could be assigned to the absence of its significant production related with the moderate phytoplankton biomass among which only a few phytoplankton species are known as FA producers. Known FA producers, such as green algae are not present and cyanobacteria are of 
Gašparović, Blaženka; Plavšić, Marta; Bošković, Nikola; Ćosović, Božena; Reigstad, Marit. Organic matter characterization in Barents Sea and eastern Arctic Ocean during summer. Marine Chemistry. 105 (2007), 1-2; 151-165. DOI: 10.1016/j.marchem.2007.01.021 - Postprint Version

limited importance in the region (Rat kova and Wassmann, 2002). FA consumption will most likely eliminate any FA accumulation in these waters since the bacterial community was well developed and active (Sturluson et al., submitted). Slightly increased FA concentrations at the depths below the UML could be an indication that fresh marine OM sinks faster than it could be transformed/consumed in the upper layer where it is produced, although the contribution of bacterial activity also could not be ruled out.

The investigations on surface-active substances revealed that the UML exhibited higher $\mathrm{SAS}_{\mathrm{T}}$ concentration, determined as equivalent to Triton-X-100 mg/l, when compared to the deeper waters, although significant SAS concentrations were detected down to $200 \mathrm{~m}$ depth. The increased concentration of SAS in the euphotic layer is often related to the new phytoplankton community production (Gašparović and Ćosović, 2003; Gašparović et al., 2005) but it may originate from other sources. For example the SAS may be a relict from previous blooms resulting from protozoan grazing on phytoplankton (Kujawinski et al. 2002). This is further supported by the significant concentrations of phaeopigment degradation products found in the region. It was shown that grazing losses in the same area and the same period of a year could be substantial (Verity et al., 2002). In general, deep-water SAS concentrations depend on the downward fluxes and the efficiency of the system for recycling.

Increased SAS"p" have been mainly found during the period of increased phytoplankton activity (Gašparović and Ćosović, 2003). It is interesting to note that in the Barents Sea the increased contribution of SAS"p" to the $\mathrm{SAS}_{\mathrm{T}}$ was found mostly in the UML and only occasionally in the deep waters. In the Arctic the particulate SAS were found in deep waters only, suggesting downward flux of particulate SAS or of advective origin. The study on vertical flux in the same region has shown moderate POC flux $\left(150-300 \mathrm{mg} \mathrm{C} \mathrm{m}^{-2} \mathrm{~d}^{-1}\right)$ out of the UML in Barents (Olli et al., 2002) and average $55 \mathrm{mg} \mathrm{C} \mathrm{m}^{-2} \mathrm{~d}^{-1}$ in the central Arctic Ocean (Olli et al., 2006). 
Gašparović, Blaženka; Plavšić, Marta; Bošković, Nikola; Ćosović, Božena; Reigstad, Marit. Organic matter characterization in Barents Sea and eastern Arctic Ocean during summer. Marine Chemistry. 105 (2007), 1-2; 151-165. DOI: 10.1016/j.marchem.2007.01.021 - Postprint Version

The surface-active organic matter in the polar region investigated was characterized by increasing hydrophilicity with the depth (Table 3). This suggests that new SAS of more hydrophobic character produced in the UML were partly removed or transformed in this layer. Freshly produced organic matter in the Arctic is labile, with high turnover rates (Dittmar and Kattner, 2003b). It was shown that neutral sugars, as indicators of OM freshness (Amon et al., 2001), are removed from the DOM pool in the upper $150 \mathrm{~m}$ water layer in the Arctic Ocean (Amon and Benner, 2003). SAS/DOC ratio, as an indicator of SAS hydrophobicity, showed a decreasing trend from south to north and from the surface to deep waters. The relatively high SAS/DOC ratio in the upper water layer could be related to the dominance of flagellates and Prymnesiophyceae in the phytoplankton community in the European Arctic and subarctic ecosystems during summer (Luchetta et al., 2000; Owrid et al., 2000; Olli et al., 2002; Rat'kova and Wassmann, 2002). Flagellates are known to produce OM of more hydrophobic properties than diatoms (Žutić et al., 1981; Vojvodić et al., 1999).and our findings lead to the conclusion that flagellates were the most likely producers of hydrophobic SAS in the Barents Sea.

The surface-active organic matter pool in the region is characterized by the dominance of neutral substances and those of very low acidity (Table 4). Such low acidity values of SAS detected at all stations and depths were surprising due to the fact that the most marine organic matter is negatively charged (Stumm, 1990). All our previous investigations in temperate regions have shown much higher SAS acidity (Gašparović et al., 1998a; 2003; 2005). Moreover, in contrast with other regions, where the acidity of SAS increases with depth due to the increased contribution of polyelectrolyte humic acids (Mopper and Shulty, 1993), the SAS acidity decreased with the depth in the northern Barents Sea and off the shelf break to the eastern Arctic Ocean. Similar to our results, Dittmar and Kattner (2003a) have found increased contribution of very small neutral molecules with largely hydrophobic functional 
Gašparović, Blaženka; Plavšić, Marta; Bošković, Nikola; Ćosović, Božena; Reigstad, Marit. Organic matter characterization in Barents Sea and eastern Arctic Ocean during summer. Marine Chemistry. 105 (2007), 1-2; 151-165. DOI: 10.1016/j.marchem.2007.01.021 - Postprint Version

groups for the region of Arctic that are not under the influence of riverine waters. Also, high neutral sugar yield (14\% DOC) in the sea-ice fresh DOM of the Arctic Ocean has been found by Amon et al. (2001). The observed low SAS acidity suggests that the investigated region is not influenced by the terrestrial $\mathrm{OM}$ that is dominated by high acidity polyelectrolyte humic type substances (Thurman, 1985). This is supported by the distribution region for the transpolar drift suggested by Anderson et al. (1994).

The area of the Arctic shelf including Barents Sea is one of the most productive area with particularly high levels of primary production in the spring (Matrai and Vernet, 1997). Prymnesiophyte Phaeocystis pouchetii in their colonial form is a producer of DMS and its precursor DMSP (dimethylsulfoniopropionate) in this area. Colonies of P. pouchetii and diatoms are both present as important bloom algae in the region. The diatoms also contribute to DMSP and DMS budget in the investigated period (Wassmann et al., 1999). The growth season in this area is May to September. The measurement of vertical flux of particulate DMSP and particulate organic sulfur species has shown the presence of these species in the water column of Arctic stations and of the Barents Sea up to $200 \mathrm{~m}$ depth with concentrations up to $40 \mu \mathrm{M}$ DMSP-S m $\mathrm{m}^{-2} \mathrm{~d}^{-1}$ for particulate DMSP and up to $40 \mathrm{mg} \mathrm{m}^{-2} \mathrm{~d}^{-1}$ for particulate organic sulfur (Matrai and Vernon, 1997). Due to the low temperatures in the Arctic seas the organic matter produced would persist for longer period of time (Wheeler et al., 1996) and so their presence is likely to occur through the whole period of phytoplankton activity i.e. period May - September. The concentrations of sulfur species we determined in the area of the Arctic and Barents Sea are likely to originate from the produced DMSP, POS and other organic sulfur compounds as a consequence of biological activity.

It is interesting to note that in the investigated region we have found mostly inorganic sulfur, with few exceptions of low concentrations of organic sulfur species as detected by electrochemical method. The presence of these forms of inorganic sulfur in these aerobic 
Gašparović, Blaženka; Plavšić, Marta; Bošković, Nikola; Ćosović, Božena; Reigstad, Marit. Organic matter characterization in Barents Sea and eastern Arctic Ocean during summer. Marine Chemistry. 105 (2007), 1-2; 151-165. DOI:

10.1016/j.marchem.2007.01.021 - Postprint Version

waters would imply that microbiological activity exerted on the in-situ formed organic matter containing sulfur. Therefore, the studies on the cycling of sulfur and on sulfur budget in the Arctic region should include inorganic sulfur species such as $\mathrm{S}^{2-}$ and $\mathrm{S}^{0}$.

\section{Conclusions}

The main characteristic of $\mathrm{OM}$ in the European Arctic polar region is the dominance of neutral surface-active substances in the entire water column during the summer. The second characteristic is increased SAS hydrophobicity in the surface waters and pronounced hydrophilicity in the deep waters. We have found that the chemical characteristics of SAS change with depth while the size of the OM pool does not change to a significant degree as revealed from DOC measurements. The surfactant activity of organic matter was increased in the productive UML when compared to the deep waters. Compared to the Barents Sea stations, lower OM pool and lower concentrations of all measured parameters were detected at the Arctic Ocean station. Increased concentrations of surface-active substances and especially of highly reactive folic acid in the layers deeper than the UML, provide the information about efficient sinking of organic matter. This study also highlights the importance of $\mathrm{S}^{2-}$ and $\mathrm{S}^{0}$ in the sulfur cycling in the region which were detected in concentrations up to $10 \mathrm{nM}$. 
Gašparović, Blaženka; Plavšić, Marta; Bošković, Nikola; Ćosović, Božena; Reigstad, Marit. Organic matter characterization in Barents Sea and eastern Arctic Ocean during summer. Marine Chemistry. 105 (2007), 1-2; 151-165. DOI: 10.1016/j.marchem.2007.01.021 - Postprint Version

\section{Acknowledgements}

This investigation was a part of the project "CABANERA" (Carbon flux and ecosystem feed back in the northern Barents Sea in an era of climate change, NFR 155936/700). Financial support of the Croatian Ministry of Science, Education and Sports, and the Norwegian Research Council, CPSSE program, project no. 149583/730 are gratefully acknowledged. Special thanks go to the project leader Dr. Paul Wassmann for general support during the project. We wish to thank Arild Sundfjord for the CTD calibration and checking the CTD data, and the divers Bjørnar Seim and Haakon Hop for collecting under-ice samples. The crew of the R/V "Jan Mayen" is also acknowledged for their invaluable support during the sampling. 
Gašparović, Blaženka; Plavšić, Marta; Bošković, Nikola; Ćosović, Božena; Reigstad, Marit. Organic matter characterization in Barents Sea and eastern Arctic Ocean during summer. Marine Chemistry. 105 (2007), 1-2; 151-165. DOI: 10.1016/j.marchem.2007.01.021 - Postprint Version

\section{References}

Aagaard, K., Carmack, E.C., 1989. The role of sea ice and other freshwater in Arctic circulation. J. Geophys. Res. C 94, 14485-14498.

Aaronson, S., Dhawale, S.W., Patni, N.J., Deangelis, B., Frank, O., Baker, H., 1977. The cell content and secretion of water- soluble vitamins by several freshwater algae. Arch. Microbiol. 112, 57-59.

Amon, R.M.W. 2004. The role of dissolved organic matter for the organic carbon cycle in the Arctic Ocean, p. 83-100. In: R. Stein and R. Macdonald [eds.], The organic carbon cycle in the Arctic Ocean. Springer-Verlag, Heidelberg Berlin.

Amon, R.M.W, Benner, R., 2003. Combined neutral sugars as indicators of the diagenetic state of dissolved organic matter in the Arctic Ocean. Deep-sea Res. I 50, 151-169.

Amon, R.M.W, Meon, B., 2004. The biogeochemistry of dissolved organic matter and nutrients in two large Arctic estuaries and potential implications for our understanding of the Arctic Ocean system. Mar. Chem. 92,311-330.

Amon, R.M.W, Fitznar, H.-P., Benner, R., 2001. Linkages among the bioreactivity, chemical composition, and diagenetic state of marine dissolved organic matter. Limnol. Oceanogr. 46, 287-297.

Anderson, L.G., Olsson, K., Skoog, A., 1994. Distribution of dissolved inorganic and organic carbon in the eurasian basin of the Arctic Ocean.. In: Johannesen, O.M., Muench, R.D., and Overland, J.E. (Eds.), The polar oceans and their role in shaping the global environment. AGU, Washington. pp. 255-262.

Andreassen, I., Nöthig, E.-M., Wassmann, P., 1996. Vertical particle flux on the shelf off northern Spitsbergen, Norway. Mar. Ecol. Prog. Ser. 137: 215-228. 
Gašparović, Blaženka; Plavšić, Marta; Bošković, Nikola; Ćosović, Božena; Reigstad, Marit. Organic matter characterization in Barents Sea and eastern Arctic Ocean during summer. Marine Chemistry. 105 (2007), 1-2; 151-165. DOI: 10.1016/j.marchem.2007.01.021 - Postprint Version

Bates, T.S., Lamb, B.K., Guenther, A.B., Dignon, J., Stoiber, R.E., 1992. Sulphur emission to the atmosphere from natural sources. J. Atmos. Chem. 14, 315-337.

Bates, T.S., Kiene, R.P., Wolfe, G.V., Matrai, P.A., Chavez, F.P., Buck, K.R., Blomquist, B.W., Cuhel, R.L., 1994. The cycling of sulphur in surface seawater of the northeast Pacific. J. Geophys. Res. 99, 7835-7843.

Ciglenečki, I, Ćosović, B., 1996. Electrochemical study of sulfur species in seawater and marine phytoplankton cultures. Mar. Chem. 52, 87-97.

Ciglenečki, I., Ćosović, B., 1997. Electrochemical determination of thiosulfate in seawater in the presence of elemental sulfur and sulfide. Electroanalysis 9, 1-7.

Ćosović, B., 1990. Adsorption kinetics of the complex mixture of organic solutes at model and natural phase boundaries, p. 291-310. In Stumm, W. [ed.], Aquatic chemical kinetics, Wiley, New York.

Ćosović, B., Vojvodić, V., 1982. The application of a.c. polarography to the determination of surface-active substances in seawater. Limnol. Oceanogr. 27, 361-369.

Ćosović, B., Vojvodić, V., 2000. Voltammetric analysis of surface-active substances in natural seawater. Electroanalysis 27, 428-435.

Dittmar, T., Kattner, G., 2003a. Recalcitrant dissolved organic matter in the ocean: major contribution of small amphyphilics. Mar. Chem. 82, 115-123.

Dittmar, T., Kattner, G., 2003b. The biogeochemistry of the river and shelf ecosystem of the Arctic Ocean: a review. Mar. Chem. 83, 103-120.

Engbrodt, R., Kattner, G., 2005. On the biogeochemistry of dissolved carbohydrates in the Greenland Sea (Arctic), Org. Geochem. 36, 937-948.

Falk-Petersen, S, Hop, H., Budgell, W.P., Hegseth, E.N., Korsnes, R., Løyning, T.B., Ørebæk, J.B., Kawamura, T., Shirasawa, K., 2000. Physical and ecological processes in 
Gašparović, Blaženka; Plavšić, Marta; Bošković, Nikola; Ćosović, Božena; Reigstad, Marit. Organic matter characterization in Barents Sea and eastern Arctic Ocean during summer. Marine Chemistry. 105 (2007), 1-2; 151-165. DOI: 10.1016/j.marchem.2007.01.021 - Postprint Version

the marginal ice zone of the northern Barents Sea during the summer melt period. J. Mar. Sys. 27, 131-159.

Fransson, A, Chierici, M., Anderson, L.C., Bussmann, I., Kattner, G., Jones, E.P., Swift, J.H., 2001. The importance of shelf processes for the modification of chemical constituents in the waters of the Eurasian Arctic Ocean: implication for carbon fluxes. Cont. Shelf Res. $21,225-242$.

Gašparović, B., Ćosović, B., 1994. Electrochemical estimation of the dominant type of surface-active substances in seawater samples using o-nitrophenol as a probe. Mar. Chem. 46, 179-188.

Gašparović, B., Ćosović, B., 1995. Electrochemical reduction of o-nitrophenol as a tool for the rough characterization of organic matter in seawater samples. Electroanalysis 7, 1136-1142.

Gašparović, B., Ćosović. B., 2001. Distribution of surface-active substances in the Northern Adriatic Sea. Mar. Chem. 75, 301-313.

Gašparović, B., Ćosović. B., 2003. Surface-active properties of organic matter in the North Adriatic Sea. Estuar. Coast. Shelf Sci. 58, 555-566.

Gašparović, B., Ćosović, B., Vojvodić, V., 1998a. Excretion of Organic Matter During an Experimental Phytoplankton Bloom Followed by Using o-Nitrophenol as an Electrochemical Probe. Croat. Chem. Acta 29, 271-284.

Gašparović, B., Ćosović, B., Vojvodić, V., 1998b. Contribution of organic acids to the pool of surface-active substances in model and marine samples using o-nitrophenol as an electrochemical probe. Org. Geochem. 29, 1025-1032.

Gašparović, B., Plavšić, M, Ćosović. B., Reigstad, M., 2005. Organic matter characterization and fate in the subarctic Norwegian fjords during late spring/summer period. Estuar. Coast. Shelf Sci. 62, 95-107.

Gašparović, B., Plavšić, M, Ćosović. B., Saliot, A., submitted. Organic matter characterization in the sea surface microlayers in the subarctic Norwegian fjords region

Hedges, J.I. 1992. Global biogeochemical cycles; progress and problems. Mar. Chem. 39, 6793. 
Gašparović, Blaženka; Plavšić, Marta; Bošković, Nikola; Ćosović, Božena; Reigstad, Marit. Organic matter characterization in Barents Sea and eastern Arctic Ocean during summer. Marine Chemistry. 105 (2007), 1-2; 151-165. DOI: 10.1016/j.marchem.2007.01.021 - Postprint Version

Hegseth, E.N., 1998. Primary production of the northern Barents Sea. Polar Res. 17, 113-123.

Holm-Hansen, O., Riemann, B., 1978. Chlorophyll a determination: improvement in methodology. Oikos 30, 438-447.

Hunter, K.A., Liss, P.S., 1982. Organic sea surface films. In: Duursma E.K., and Dawson, R. (Eds.), Marine Organic Chemistry. Elsevier, Amsterdam, pp. 259-298.

Kujawinski, E.B., Farrington, J.W., Moffett, J.W., 2002. Evidence for grazing-mediated production of dissolved surface-active material by marine protist. Mar. Chem. 77, 133142.

Krznarić, D., Ciglenečki, I., Ćosović, B., 2001. Voltammetric investigations of 2imethylarsinyl-ethanol sulfide in $\mathrm{NaCl}$ and seawater. Anal. Chim. Acta 431, 269-278.

Le Gall, A.C., Van Den Berg, C.M.G., 1998. Folic acid and glutathione in the water column of the North East Atlantic. Deep-sea Res. I 45, 1903-1918.

Luchetta, A., Lipizer, M., Socal, M., 2000. Temporal evolution of primary production in the central Barents Sea. J. Mar. Sys. 27, 177-193.

Matrai, P.A., Vernet, M., 1997. Dynamics of vernal bloom in the marginal ice zone of Barents Sea: Dimethyl sulfide and dimethylsulfoniopropionate budgets. J. Geophys. Res. 102/C10, 22965-22979.

Midttung, L. 1985. Formation of dense bottom water in the Barents Sea. Deep-Sea Res. 32, $1233-1241$.

Mopper K., Shultz, C.A., 1993. Fluorescence as a possible tool for studying the nature and water column distribution of DOC components. Mar. Chem. 41, 229-238.

Ogawa, H., Tanoue, E., 2003. Dissolved organic matter in oceanic waters. J. Oceanogr. 59, 129-147. 
Gašparović, Blaženka; Plavšić, Marta; Bošković, Nikola; Ćosović, Božena; Reigstad, Marit. Organic matter characterization in Barents Sea and eastern Arctic Ocean during summer. Marine Chemistry. 105 (2007), 1-2; 151-165. DOI: 10.1016/j.marchem.2007.01.021 - Postprint Version

Olli, K., Wexels Riser, C., Wassmann, P, Ratkova, T., Arashkevich, E., Pasternak, A., 2002. Seasonal variation in vertical flux of biogenic matter in the marginal ice zone and the central Barents Sea. J. Mar. Sys. 38, 189-204.

Olli, K., Wassmann, P., Reigstad, M., Ratkova, T.N, Arashkevich. E., Pasternak, A., Matrai, P., Knulst, J., Tranvik, L., Klais, R., Jakobsen, A. The fate of production in the central Arctic Ocean - top-down regulation by zooplankton expatriates. Prog. Oceanogr. In press.

Owrid, G., Socal, G., Civitarese, G., Luchetta, A., Wiktor, J, Nöthig, E.-M., Andreassen, I., Schauer, U., Strass, V., 2000. Spatial variability of phytoplankton, nutrients and new production estimates in the waters around Svalbard. Polar Research 19, 155-171.

Plavšić, M., 2004. Long term investigations of folic acid concentrations in the Northern Adriatic. Environ. Int. 30, 761-767.

Plavšić, M., Lu, X., Van Den Berg, C.M.G., 1997. A voltammetric study of the reactivity of folic acid in algal cultures and in natural waters. Croat. Chem. Acta 70, 179-91.

Plavšić, M., Terzić, S., Ahel, M., Van Den Berg, C.M.G., 2002. Folic acid in coastal waters of the Adriatic Sea. Mar. Fresh. Res. 53, 1245-1252.

Ratkova, T.N., Wassmann, P, 2002. Seasonal variation and spatial distribution of phyto-and protozooplankton in the central Barents Sea. J. Mar. Sys. 38, 47-75.

Reigstad. M., Wassmann, P, Wexels Riser, C., Øjgarden, S., Rey, F., 2002. Variations in hydrography, nutrients and chlorophyll $a$ in the marginal ice-zone and the central Barents Sea. J. Mar. Sys. 38, 9-29.

Sakshaug, E. 2004. Primary and secondary production in the Arctic Seas. In: Stein, R and Macdonald, R.W. (Eds.). The organic carbon cycle in the Arctic Ocean. Springer-Verlag, Berlin Heidelberg, pp. 57-81. 
Gašparović, Blaženka; Plavšić, Marta; Bošković, Nikola; Ćosović, Božena; Reigstad, Marit. Organic matter characterization in Barents Sea and eastern Arctic Ocean during summer. Marine Chemistry. 105 (2007), 1-2; 151-165. DOI: 10.1016/j.marchem.2007.01.021 - Postprint Version

Stumm W. (Ed.), Aquatic Chemical Kinetics, New York, Wiley, 1990.

Sturluson M., Nielsen, T.G., Wassmann, P. Bacterial abundance, biomass and production during spring bloom in the northern Barents Sea. Submitted to the Mar. Biol. Res.

Sundfjord, A., Fer, I., Kasajima, Y., Svendsen, H. Observations of turbulent mixing and hydrography in the Marginal Ice Zone of the Barents Sea. J. Geophys. Res. In press.

Verity, P.G., Wassmann, P, Ficher, M.E., Howard-Jones, M.H., Allen, A.E., 2002. Seasonal C-cycling variability in the open and ice-covered waters of the Barents Sea: an introduction. J. Mar. Sys. 38, 109-123.

Vojvodić, V., Ćosović, B. Mirić, V., 1994. Fractionation of surface-active substances on the XAD-8 resin. Part I. Mixtures of model substances. Anal. Chim. Acta. 295, 73-83.

Vojvodić, V., Ćosović, B., Cauwet, G., Gašparović, B., Kodba, Z. 1999. Variability of surface-active organic material in the northern Adriatic. Ecosystems research report No. 32. The Adriatic Sea. Luxembourg : European Commission, Directorate - General for Research, 281-294.

Wassmann, P, Ratkova, T.N., Andreassen, I., Vernet, M., Pedersen, C., Rey, F., 1999. Spring bloom development in the marginal ice zone and the central Barents Sea. Mar. Ecol.Pubbl. Stn. Zool. Napoli 20: 321-346.

Wassmann, P, Slagstad, D., Wexels Riser, C., Reigstad. M., 2006 Modelling the ecosystem dynamics of the marginal ice zone and central Barents Sea. II. Carbon flux and climate variability. J. Mar. Sys. 59, 1-24.

Wheeler P.A., Gosselin, M, Sherr, E, Thibault, D, Kirchman, D.L., Benner, R., Whitledge, T.E. 1996. Active cycling of organic carbon in the central Artic Ocean. Nature 380, 697699.

Žutić, V., Ćosović, B., Marčenko, E., Bihari, N., Kršinić, F., 1981. Surfactant production by marine phytoplankton. Mar. Chem. 10, 505-520. 
Gašparović, Blaženka; Plavšić, Marta; Bošković, Nikola; Ćosović, Božena; Reigstad, Marit. Organic matter characterization in Barents Sea and eastern Arctic Ocean during summer. Marine Chemistry. 105 (2007), 1-2; 151-165. DOI: 10.1016/j.marchem.2007.01.021 - Postprint Version

\section{Figure captions:}

Fig. 1. Sampling stations in the investigated area of the Arctic (Station VII) and the Barents Sea (Stations IX, X, XI and XIII).

Fig. 2. Voltammetric scans of Barents Sea sample, station XI, $10 \mathrm{~m}$. Peak 1 indicates the presence of sulphur, while peak 2 is the consequence of the presence of folic acid (peak 2a: original sample; peak $2 \mathrm{~b}$ : with addition of $4 \mathrm{nM} \mathrm{FA}$; peak $2 \mathrm{c}$ : with addition of $8 \mathrm{nM} \mathrm{FA}$ ).

Fig. 3. The capacitive current-potential curves for samples from station X, depth $5 \mathrm{~m}$ (curve 3) and $150 \mathrm{~m}$ (curve 2). Accumulation time: $120 \mathrm{~s}$. Curve 1 is obtained without accumulation and without adsorption effect.

Fig. 4. Vertical profiles of temperature (8) and salinity (-) variations for the investigated stations.

Fig. 5. Vertical profiles of pigments $C h l a$ (full line, closed symbols) and phaeopigments (dotted line, open symbols) for the investigated stations.

Fig. 6. Distribution of folic acid (FA) $\left(\mathrm{nmol} \mathrm{1}^{-1}\right)$ along the depth profile for the investigated stations.

Fig. 7. Distribution of $\mathrm{SAS}_{\mathrm{T}}$ (full line, closed symbols) and SAS"p" (dotted line, open symbols) in equiv. of T-X-100 (mg $\left.\mathrm{m}^{-1}\right)$, for the investigated stations.

Fig. 8. Dissolved SAS (in equiv. of T-X-100, $\mathrm{mg} \mathrm{l}^{-1}$ ) vs. DOC. Barents Sea and Arctic UML samples are presented with open square $(\forall)$ while deep water samples are presented by closed square (!). Lines represent SAS-DOC correlations for the selected model substances: fulvic acid (curve 1), protein albumin (curve 2) and high molecular acidic polysaccharide xanthan 
Gašparović, Blaženka; Plavšić, Marta; Bošković, Nikola; Ćosović, Božena; Reigstad, Marit. Organic matter characterization in Barents Sea and eastern Arctic Ocean during summer. Marine Chemistry. 105 (2007), 1-2; 151-165. DOI: 10.1016/j.marchem.2007.01.021 - Postprint Version

(curve 3). Data are compared to the Northern Adriatic Sea ( $\square$ ) and to the North Norwegian fjords and shelf waters; UML (8) and deep waters (7).

\section{Table captions:}

Table 1. Sampling date, station annotation, geographical location and position (latitude and longitude) of the sampling sites. Station and sampling depths are also given.

Table 2. Dissolved organic carbon (DOC).

Footnote:

${ }^{1}$ not collected

Table 3. SAS/DOC ratios evaluated for the investigated stations and depths. Results are compared to the SAS/DOC values of model substances representative for the major classes of organic compounds present in the seawater (Gašparović et al., submitted).

Footnote:

${ }^{1}$ not collected

Table 4. Average relative acidity values evaluated for the investigated stations in the Barents Sea (Stations X, X1, and XIII) and the Arctic (Station VII) compared to the relative acidity values of the samples taken in subpolar Norwegian fjords (Gašparović et al., 2005) and from the Mediterranean region (Gašparović, unpublished data).

Table 5. Values of measured parameters for the under-ice samples.

Footnote:

${ }^{1}$ normalized to DOC value in $\mathrm{mg}^{-1}$.

${ }^{2}$ not measured

Table 6. Concentrations of sulfur species for the investigated stations and depths.

Footnote: 
Gašparović, Blaženka; Plavšić, Marta; Bošković, Nikola; Ćosović, Božena; Reigstad, Marit. Organic matter characterization in Barents Sea and eastern Arctic Ocean during summer. Marine Chemistry. 105 (2007), 1-2; 151-165. DOI:

10.1016/j.marchem.2007.01.021 - Postprint Version

${ }^{1}$ bellow detection limit

${ }^{2}$ not measured

${ }^{3}$ not collected 
Table 1.

\begin{tabular}{ccccccc}
\hline Date & Station & Location & Latitude ${ }^{\circ} \mathbf{N}$ & Longitude ${ }^{\circ} \mathbf{E}$ & Depth (m) & $\begin{array}{c}\text { Sampling depth } \\
\text { range (m) }\end{array}$ \\
\hline $23-07-04$ & VII & Nansen Basin & $82^{\circ} 24.9$ & $29^{\circ} 26.2$ & 3500 & $1-500$ \\
$24-07-04$ & & & & & \\
\hline $25-07-04$ & IX & N Kong Karlsland & $79^{\circ} 23.9$ & $28^{\circ} 41.7$ & 300 & $1-295$ \\
\hline $27-07-04$ & X & N Kong Karlsland & $79^{\circ} 22.7$ & $28^{\circ} 41.6$ & 300 & $1-200$ \\
$28-07-04$ & & & & & & \\
\hline $29-07-04$ & XI & NE Kong Karlsland & $79^{\circ} 49.4$ & $29^{\circ} 43.6$ & 200 & $1-200$ \\
$30-07-04$ & & & & & & 160 \\
\hline $31-07-04$ & XIII & W Kvitøya & $79^{\circ} 56.3$ & $30^{\circ} 56.6$ & $1-130$ \\
$01-08-04$ & & & & & & \\
\hline
\end{tabular}


Gašparović, Blaženka; Plavšić, Marta; Bošković, Nikola; Ćosović, Božena; Reigstad, Marit. Organic matter characterization in Barents Sea and eastern Arctic Ocean during summer. Marine Chemistry. 105 (2007), 1-2; 151-165. DOI:

10.1016/j.marchem.2007.01.021 - Postprint Version

Table 2.

\begin{tabular}{|c|c|c|c|c|c|}
\hline \multirow{3}{*}{ Depth, m } & \multicolumn{5}{|c|}{ DOC, $\mu \mathrm{mol} \mathrm{l}^{-1}$} \\
\hline & \multirow{2}{*}{$\begin{array}{l}\text { Arctic } \\
\text { VII }\end{array}$} & \multicolumn{4}{|c|}{ Barents Sea } \\
\hline & & XIII & XI & $\mathbf{X}$ & IX \\
\hline 1 & 67.0 & 72.2 & 74.2 & 72.3 & 69.0 \\
\hline 5 & 66.9 & 75.0 & 74.3 & 69.9 & 69.8 \\
\hline 10 & 67.9 & 74.8 & 74.4 & 72.1 & 67.1 \\
\hline 20 & 65.4 & 71.2 & 71.7 & 66.3 & 67.9 \\
\hline 30 & 68.8 & 72.2 & 73.8 & 67.3 & 66.3 \\
\hline 40 & 63.3 & 71.7 & 71.3 & 66.7 & 65.4 \\
\hline 50 & 64.8 & 70.2 & 71.3 & 67.3 & 66.2 \\
\hline 60 & 61.7 & 70.8 & 69.0 & 66.3 & 66.3 \\
\hline 90 & 61.1 & 73.9 & 69.5 & 66.2 & 65.3 \\
\hline 120 & 59.5 & 70.4 & 66.7 & $\mathrm{~N} / \mathrm{C}^{1}$ & 65.4 \\
\hline 130 & $\mathrm{~N} / \mathrm{C}$ & 69.0 & $\mathrm{~N} / \mathrm{C}$ & $\mathrm{N} / \mathrm{C}$ & $\mathrm{N} / \mathrm{C}$ \\
\hline 150 & 61.4 & & 70.7 & 65.2 & 63.8 \\
\hline 200 & 61.5 & & 69.3 & 64.2 & 62.0 \\
\hline 250 & 62.9 & & & & 62.2 \\
\hline 300 & 63.4 & & & & 61.6 \\
\hline 350 & 59.9 & & & & \\
\hline 400 & 60.4 & & & & \\
\hline 450 & 62.0 & & & & \\
\hline 500 & 64.6 & & & & \\
\hline
\end{tabular}


Gašparović, Blaženka; Plavšić, Marta; Bošković, Nikola; Ćosović, Božena; Reigstad, Marit. Organic matter characterization in Barents Sea and eastern Arctic Ocean during summer. Marine Chemistry. 105 (2007), 1-2; 151-165. DOI:

10.1016/j.marchem.2007.01.021 - Postprint Version

Table 3.

\begin{tabular}{|c|c|c|c|c|c|}
\hline \multirow{3}{*}{ Depth, m } & \multicolumn{5}{|l|}{ SAS/DOC } \\
\hline & \multirow{2}{*}{$\frac{\text { Arctic }}{\text { VII }}$} & \multicolumn{4}{|c|}{ Barents Sea } \\
\hline & & XIII & $\mathbf{X I}$ & $\mathbf{X}$ & IX \\
\hline 1 & 0.052 & 0.102 & 0.118 & 0.113 & 0.121 \\
\hline 5 & 0.062 & 0.117 & 0.129 & 0.101 & 0.116 \\
\hline 10 & 0.061 & 0.117 & 0.094 & 0.113 & 0.123 \\
\hline 20 & 0.061 & 0.080 & 0.053 & 0.086 & 0.115 \\
\hline 30 & 0.065 & 0.092 & 0.051 & 0.093 & 0.111 \\
\hline 40 & 0.066 & 0.053 & 0.054 & 0.055 & 0.048 \\
\hline 50 & 0.054 & 0.036 & 0.068 & 0.089 & 0.054 \\
\hline 60 & 0.057 & 0.067 & 0.054 & 0.064 & 0.082 \\
\hline 90 & 0.057 & 0.043 & 0.044 & 0.088 & 0.051 \\
\hline 120 & 0.045 & 0.038 & 0.050 & $\mathrm{~N} / \mathrm{C}^{1}$ & 0.065 \\
\hline 130 & $\mathrm{~N} / \mathrm{C}$ & 0.036 & $\mathrm{~N} / \mathrm{C}$ & $\mathrm{N} / \mathrm{C}$ & $\mathrm{N} / \mathrm{C}$ \\
\hline 150 & 0.038 & & 0.054 & 0.032 & 0.074 \\
\hline 200 & 0.038 & & 0.032 & 0.044 & 0.069 \\
\hline 250 & $\mathrm{~N} / \mathrm{C}$ & & & & 0.076 \\
\hline 300 & 0.029 & & & & 0.046 \\
\hline 400 & 0.044 & & & & \\
\hline 500 & 0.072 & & & & \\
\hline \multirow{3}{*}{$\begin{array}{c}\text { Model } \\
\text { substances }\end{array}$} & Linoleic & Humic & Plysaccharide & Protein & Plysaccharide \\
\hline & acid & acid & Dextran & Albumin & Xanthan \\
\hline & 2.39 & 0.34 & 0.30 & 0.19 & 0.04 \\
\hline
\end{tabular}


Table 4 .

\begin{tabular}{ccc|cc}
\hline \multirow{2}{*}{ Region } & & \multirow{2}{*}{$\begin{array}{c}\text { Number of } \\
\text { samples }\end{array}$} & \multicolumn{2}{c}{ Relative acidity, $1 \mathrm{mg}^{-1}$} \\
\cline { 3 - 5 } & & 22 & 3.6 & $0-11.6$ \\
Barents Sea & UML & 10 & 2.4 & $2.8-8.6$ \\
\hline Arctic & deep waters & 6 & 5.6 & $0-7.3$ \\
& UML & 10 & 4.7 & $0-12.1$ \\
\hline North Norwegian & deep waters & 33 & 14.2 & $8.2-26.3$ \\
fjords & UML & 20 & 15.4 & $9.0-25.0$ \\
\hline Western & deep waters & 7 & 11.1 & $7.7-13.9$ \\
Mediterranean & surface waters & & & \\
\hline Northern Adriatic & entire water profile & 11 & 13.7 & $8.2-29.5$ \\
& $(0-35$ m) & & & \\
\hline
\end{tabular}


Gašparović, Blaženka; Plavšić, Marta; Bošković, Nikola; Ćosović, Božena; Reigstad, Marit. Organic matter characterization in Barents Sea and eastern Arctic Ocean during summer. Marine Chemistry. 105 (2007), 1-2; 151-165. DOI: 10.1016/j.marchem.2007.01.021 - Postprint Version

Table 5.

\begin{tabular}{|c|c|c|c|c|}
\hline \multicolumn{5}{|l|}{ Under-ice samples } \\
\hline & Arctic & Barents & & \\
\hline & VII & XI & $\mathbf{X}$ & IX \\
\hline $\mathrm{DOC}$ & 83.7 & 49.3 & 63.9 & 67.7 \\
\hline $\mathrm{SA}, \mathrm{mg}_{\mathrm{T}-\mathrm{X}-100 \mathrm{l}^{-1}}$ & 0.08 & 0.074 & 0.078 & $\mathrm{~N} / \mathrm{M}^{2}$ \\
\hline Relative acidity, $1 \mathrm{mg}^{-1}$ & 4.5 & 2.0 & 0 & $\mathrm{~N} / \mathrm{M}$ \\
\hline SAS/DOC ${ }^{1}$ & 0.080 & 0.125 & 0.1 & $\mathrm{~N} / \mathrm{M}$ \\
\hline $\mathrm{FA}, \mathrm{nmol} \mathrm{l}^{-1}$ & 0.2 & 3.0 & 0.4 & $\mathrm{~N} / \mathrm{M}$ \\
\hline Sulfur, nmol 1 $^{-1}$ & 4 & $<2$ & 7 & $\mathrm{~N} / \mathrm{M}$ \\
\hline
\end{tabular}


Gašparović, Blaženka; Plavšić, Marta; Bošković, Nikola; Ćosović, Božena; Reigstad, Marit. Organic matter characterization in Barents Sea and eastern Arctic Ocean during summer. Marine Chemistry. 105 (2007), 1-2; 151-165. DOI:

10.1016/j.marchem.2007.01.021 - Postprint Version

Table 6.

\begin{tabular}{ccccc}
\hline \multirow{4}{*}{ Depth, m } & \multicolumn{4}{l}{ Sulfur, nmol l-1 } \\
\cline { 2 - 5 } & $\begin{array}{c}\text { Arctic } \\
\text { VII }\end{array}$ & Barents Sea & \\
& XIII & XI & X \\
\hline 1 & 4 & 4 & 10 & 3 \\
5 & 4 & 4 & 6 & 5 \\
10 & 4 & 6 & 2 & 5 \\
20 & 5 & $<2$ & 4 & 5 \\
30 & 2 & 5.5 & $<2$ & 8 \\
40 & 5 & 5 & 3 & BDL $^{1}$ \\
50 & 3 & 3 & 4 & 8 \\
60 & 4 & 3 & 4 & $\mathrm{BDL}^{-1}$ \\
90 & 4 & $<2$ & 5 & 3 \\
120 & 2 & 5 & 5 & $\mathrm{~N} / \mathrm{M}^{2}$ \\
130 & $\mathrm{~N} / \mathrm{C}^{3}$ & 5 & $\mathrm{~N} / \mathrm{C}$ & $\mathrm{N} / \mathrm{M}$ \\
150 & 3.5 & & $<2$ & $\mathrm{~N} / \mathrm{M}$ \\
200 & 4 & & 4 & $\mathrm{~N} / \mathrm{M}$ \\
300 & 4.5 & & & \\
400 & 3.5 & & & \\
500 & $<2$ & & & \\
\hline
\end{tabular}


Fig. 1.

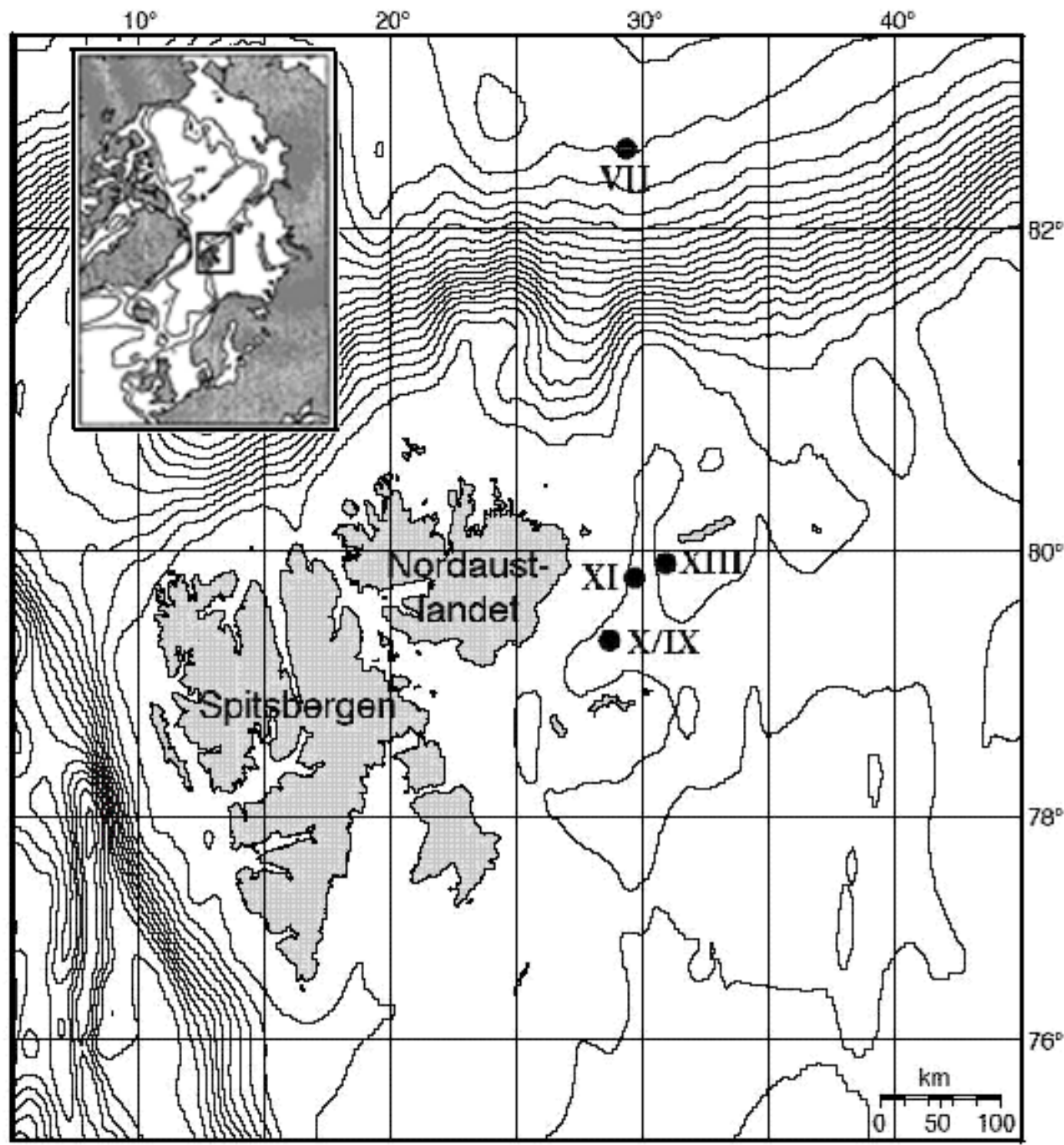

Gašparović et al. 
Fig. 2.

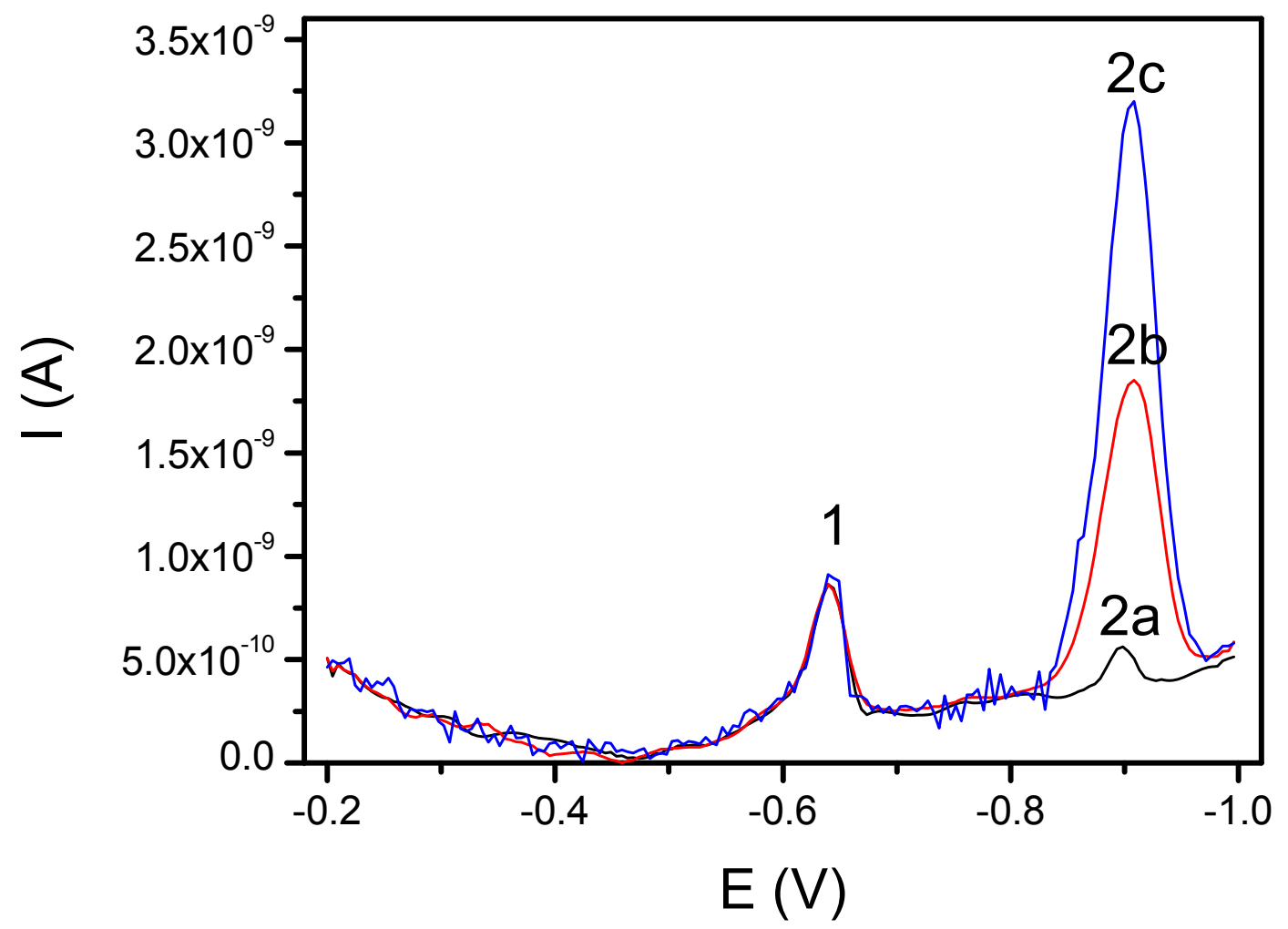

Gašparović et al. 
Fig. 3.

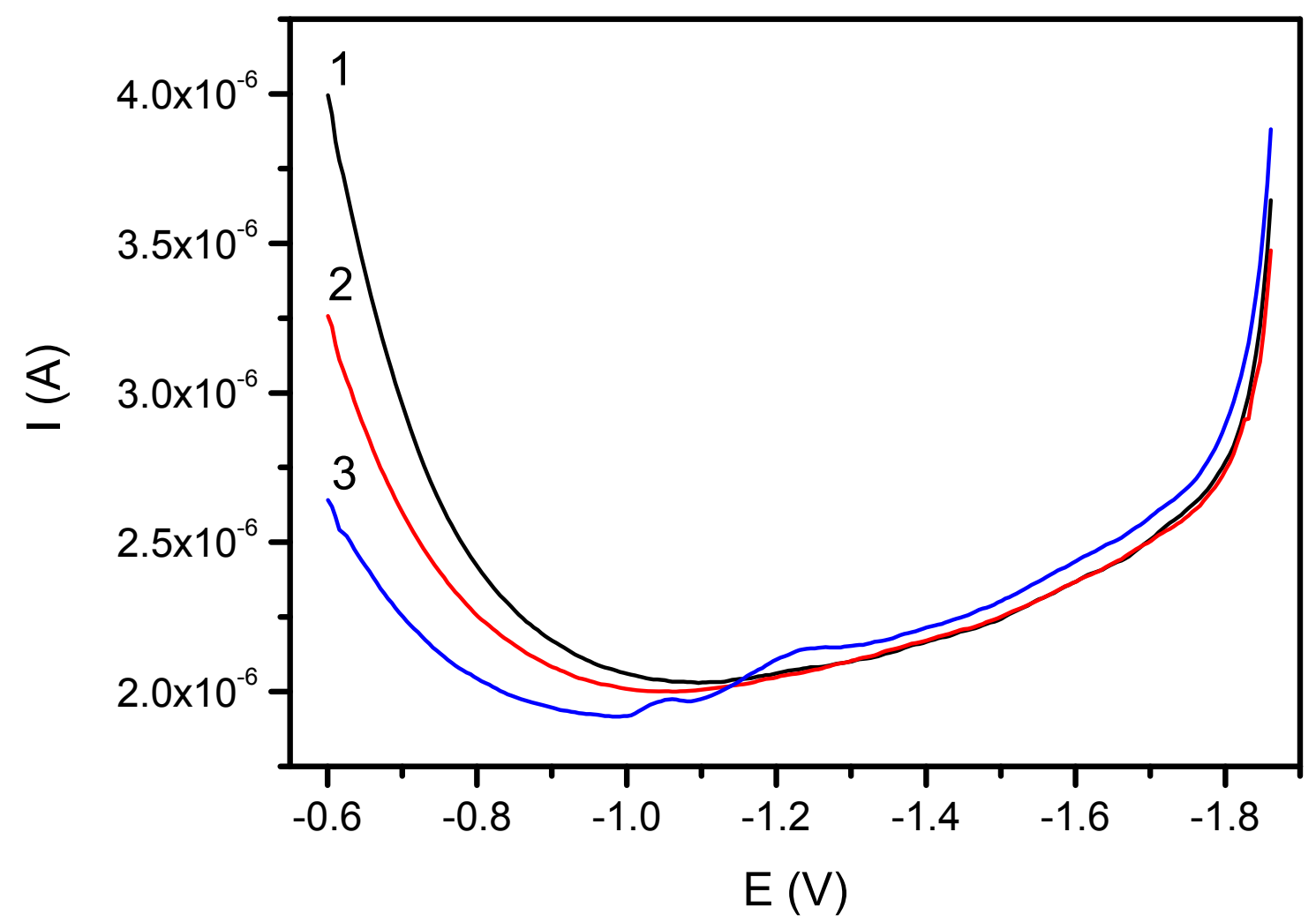

Gašparović et al. 
Gašparović, Blaženka; Plavšić, Marta; Bošković, Nikola; Ćosović, Božena; Reigstad, Marit. Organic matter characterization in Barents Sea and eastern Arctic Ocean during summer. Marine Chemistry. 105 (2007), 1-2; 151-165. DOI:

10.1016/j.marchem.2007.01.021 - Postprint Version

Fig. 4.

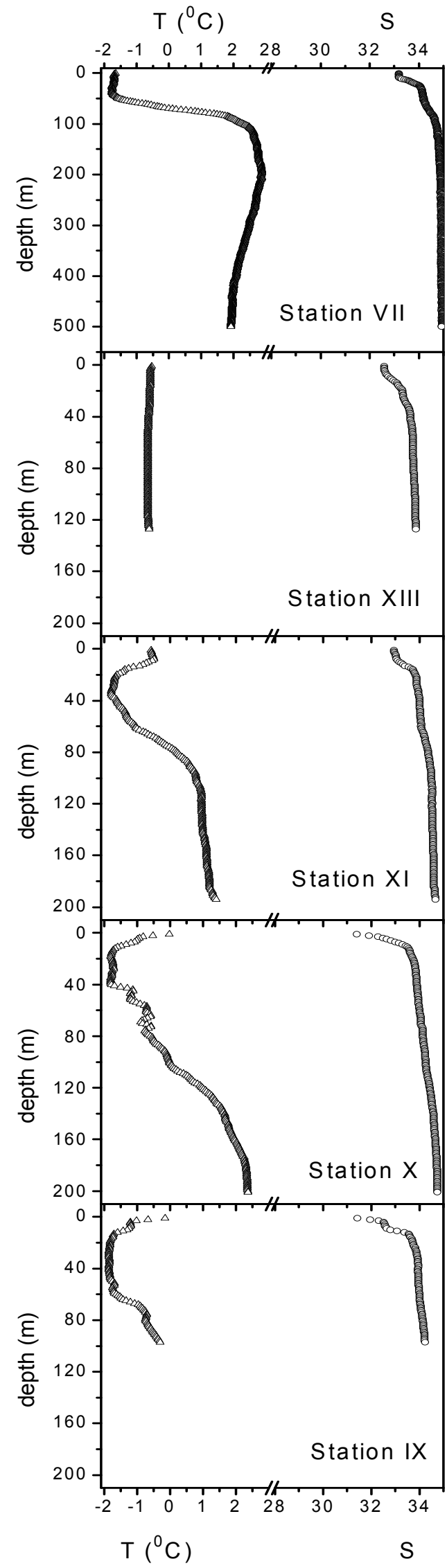

Gašparović et al. 
Fig. 5.
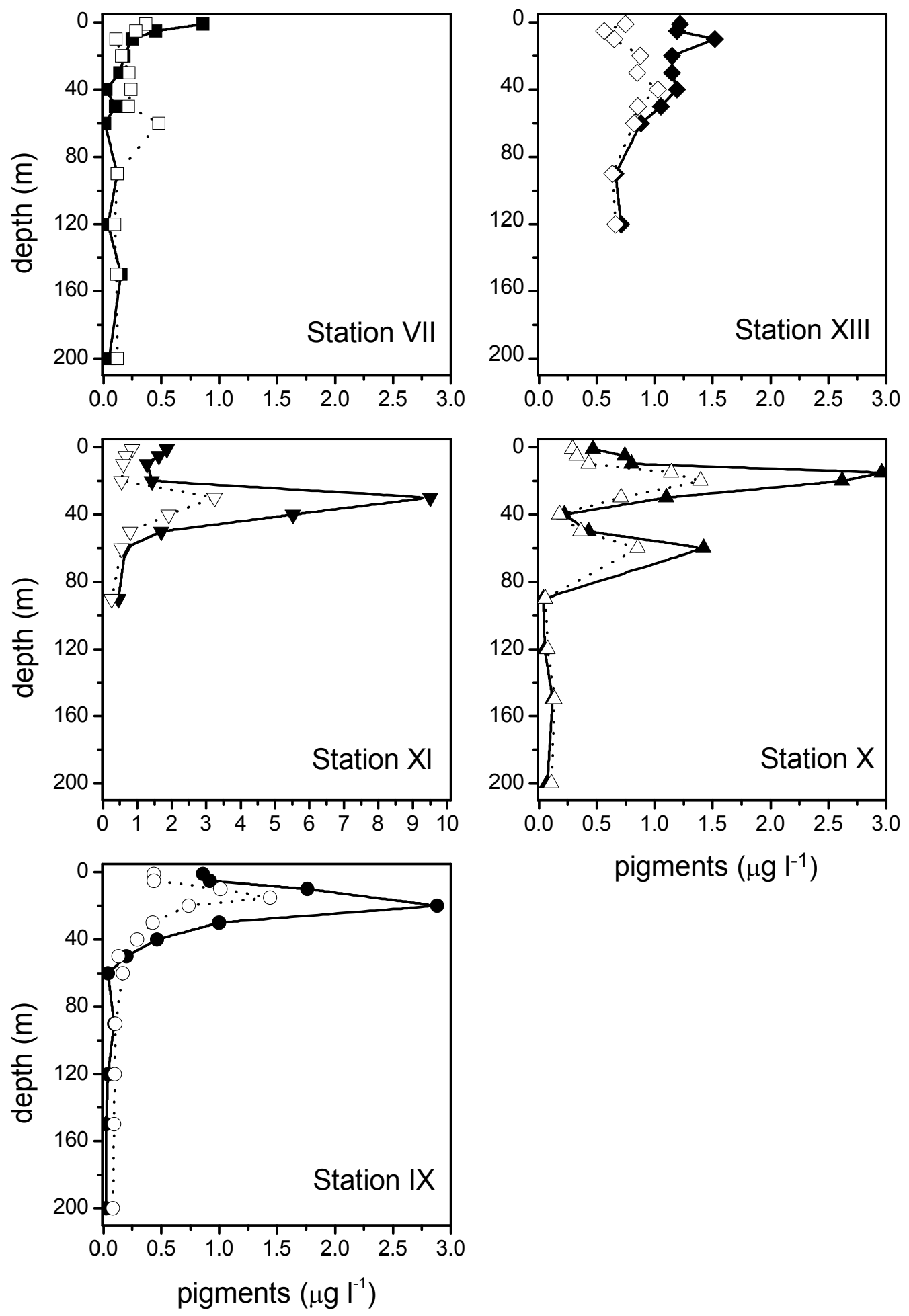

pigments $\left(\mu \mathrm{g} \mathrm{l}^{-1}\right)$

Gašparović et al. 
Gašparović, Blaženka; Plavšić, Marta; Bošković, Nikola; Ćosović, Božena; Reigstad, Marit. Organic matter characterization in Barents Sea and eastern Arctic Ocean during summer. Marine Chemistry. 105 (2007), 1-2; 151-165. DOI:

10.1016/j.marchem.2007.01.021 - Postprint Version

Fig. 6.

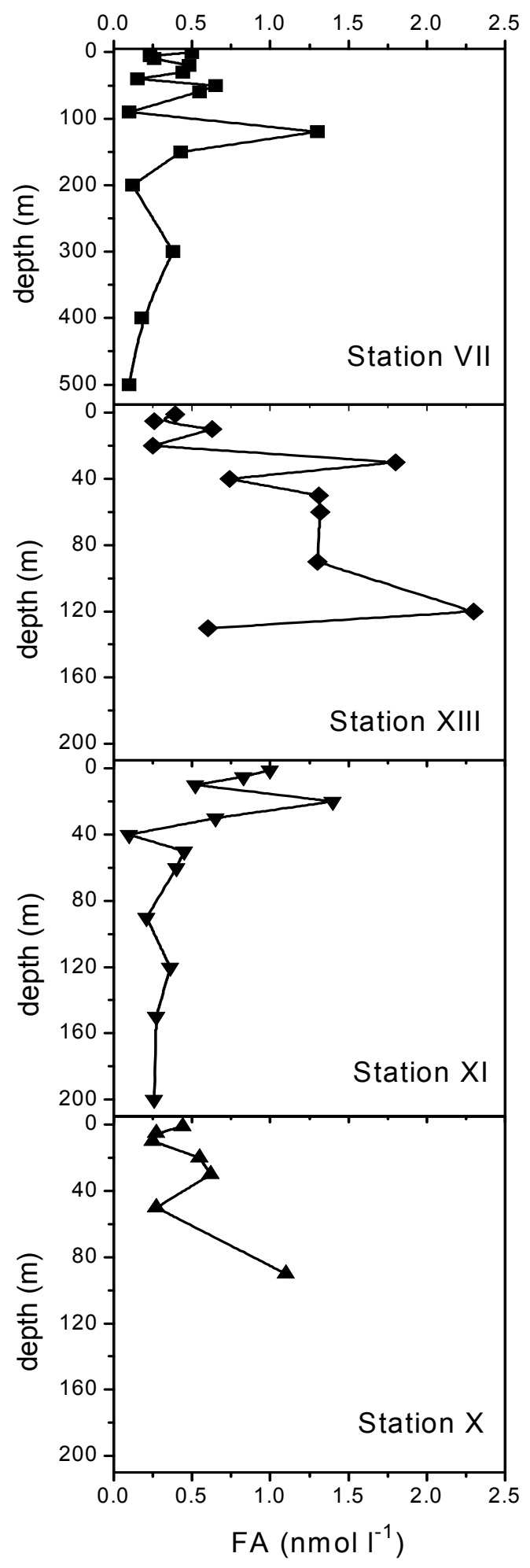

Gašparović et al. 
Gašparović, Blaženka; Plavšić, Marta; Bošković, Nikola; Ćosović, Božena; Reigstad, Marit. Organic matter characterization in Barents Sea and eastern Arctic Ocean during summer. Marine Chemistry. 105 (2007), 1-2; 151-165. DOI:

10.1016/j.marchem.2007.01.021 - Postprint Version

Fig. 7.

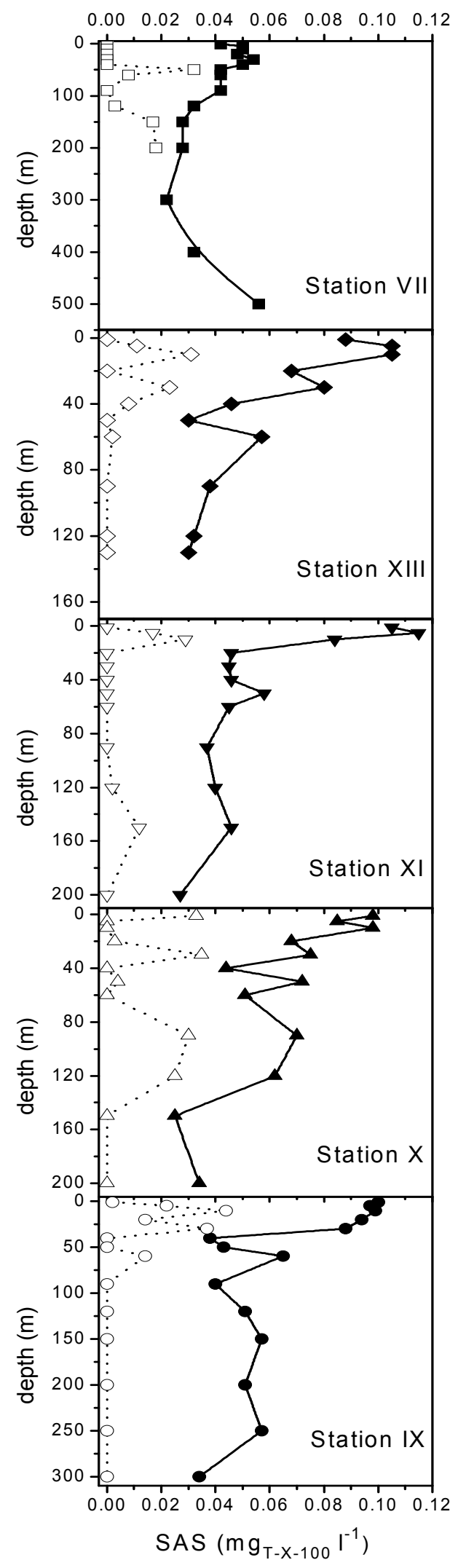

Gašparović et al. 
Fig. 8.

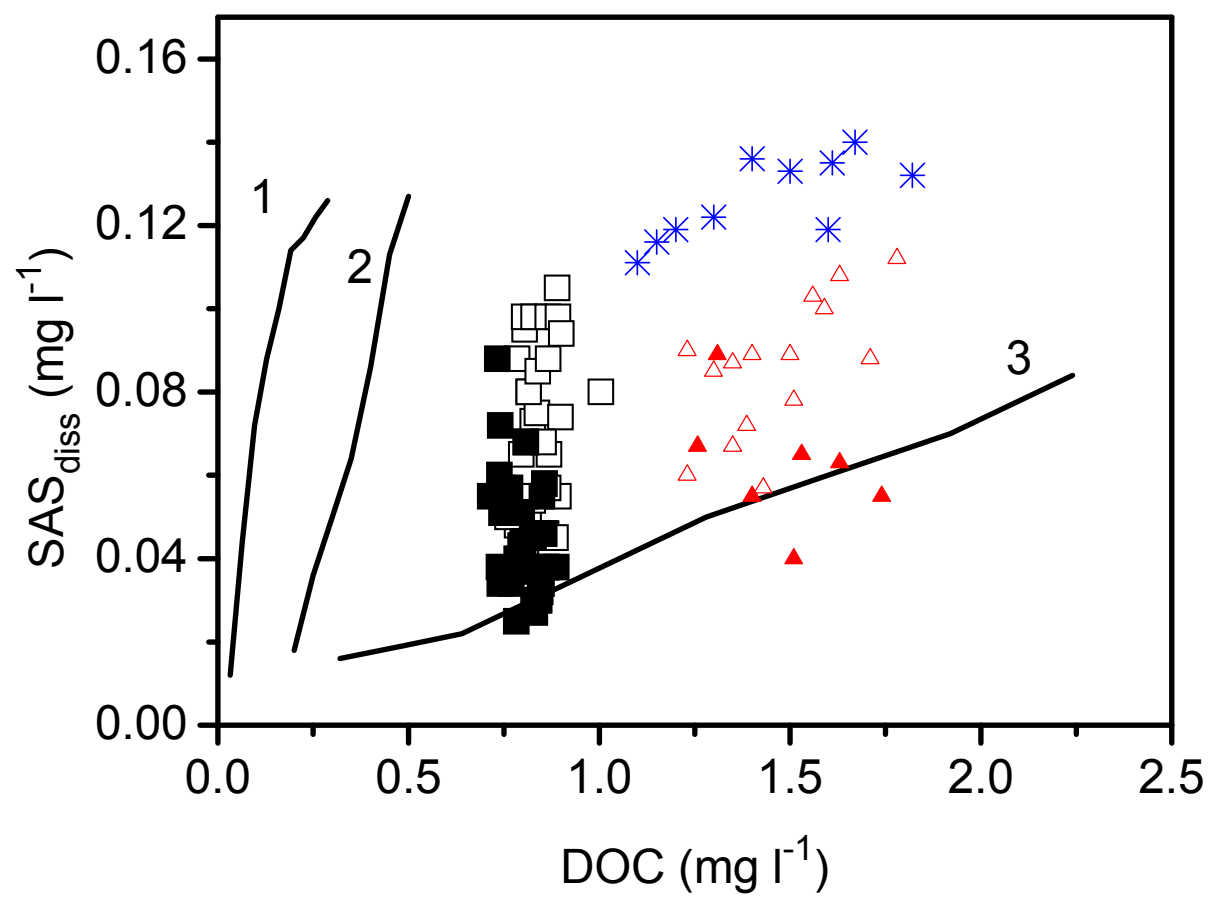

Gašparović et al. 
Gašparović, Blaženka; Plavšić, Marta; Bošković, Nikola; Ćosović, Božena; Reigstad, Marit. Organic matter characterization in Barents Sea and eastern Arctic Ocean during summer. Marine Chemistry. 105 (2007), 1-2; 151-165. DOI:

10.1016/j.marchem.2007.01.021 - Postprint Version 